\title{
LIFELONG LEARNING: THE NEW EDUCATIONAL PARADIGM FOR SUSTAINABLE DEVELOPMENT
}

\author{
Venelin Terziev \\ Academician of the Russian Academy of Natural History, Moscow, Russia, Prof. D.Sc. (Ec.), D.Sc. \\ (National Security), D.Sc. (Social Activities), Ph.D., National Military University, Veliko Tarnovo, \\ Bulgaria; University of Rousse, Rousse, Bulgaria, terziev@skmat.com
}

\begin{abstract}
The paper examines life-long strategies in international and national scope and opportunities to adopt their priorities in regional strategies for improving level and access to lifelong learning in the Republic of Bulgaria. The issues are discussed from the point of view of lifelong learning's advantages that could be used for providing training in less favored regions considering capacity building for achievement of sustainable development. The study provides evidence that lifelong learning development would have a specific contribution to the strategic goals of increase in educational level and employment rates, promotion of research and development, reducing poverty and uneven development of urban and rural areas through a self-directed learning process providing solutions of the most topical problems concerning low economic development, lack of managerial and marketing skills, and thus contributing to more general points of improvement of living conditions, food and social security, etc.
\end{abstract}

Keywords: lifelong learning, learning outcomes, competence-based training.

\section{INTRODUCTION}

In today's economy the economic growth, development and progress of an economy are subject to investment in people, to the increased role of education and lifelong learning and improving educational and employment policies. The importance of lifelong learning on the labor market is underlined in the increase of work efficiency because „by participating in lifelong learning individuals adapt more easily to changes in the labour market and better face strong competition from the global economy" and these advantages on individual level are supported by the advantages on organization and even national level "by the fact that well prepared people are always a long-term investment of society, becoming the support of economic growth and development" (Lonela, 2012a)

Addressing strategic goals in the beginning of the new millennium the educational level is one of the most prominent fields of discussion both as a target and as a factor in future development. The establishment of educational standards aiming at enhancing creativity and innovation is a feature of new development goals respecting cultural differences and applying new technology development. Targeted changes in educational systems are to provide quality, efficiency, mobility, recognition, and competence. There are six outlined 
dimensions that are determined by quality education: inclusiveness; effectiveness; health, safety and productive school environment; gender equality; participation and active participation of all stakeholders in the life and work of the school environment; respecting the rights of children and multiculturalism (JovanovaMitkovska, Hristovska, 2011b).

\section{LIFELONG LEARNING: THE NEW EDUCATIONAL PARADIGM FOR SUSTAINABLE DEVELOPMENT}

Lifelong learning („education from cradle to grave”) is a holistic approach having as main targets "generalizing the pre-school education both in quantity and quality, constituting a real learning basis in compulsory education, facilitating progression from school to business life, encouraging adults to learn, renewing the resources of the system and establishing consistency between the parts of the system" (Demirel, 2009a). Lifelong learning comprises all phases of learning, from pre-school to post-retirement, and covers the whole spectrum of formal, non-formal and informal learning which means that learning is a diverse process adapted to the individuals and occurring at all times in all places providing not only individual needs "in order to foster the continuous development and improvement of the knowledge and skills needed for employment and personal fulfillment" but also community ones. Lifelong learning is defined as "lifelong, lifewide, voluntary and self-motivated pursuit of knowledge for either personal of professional reasons" enhancing social inclusion, active citizenship and personal development, competitiveness and employability. Life-long learning as „deliberate, focused learning throughout a person's lifetime” is connected to studentcentered learning approaches.

Taking the basic differences between educational perspective of the 20th century and the concept of the lifelong learning in the 21st century, the changing function of educational institutions and the interaction between schools and lifelong learning is displayed underlining that "schools in the twenty-first century should be restructured in a unity of system which allows for equal opportunities for all students without exception, which is production-based, suitable for the existing vocational standards, which allows horizontal/vertical transfers in all periods of education, and finally which teaches the ways and methods for obtaining knowledge with an approach of lifelong learning for all". What is important for learners are learning how to learn and the ability to organize and direct their own learning skills. The differences between the concept of 20th century education and the concept of 21 st century lifelong learning (Table 1) are stated by Longworth (2003).

Table 1. Differences between 20th century education and 21st century lifelong learning

\begin{tabular}{|l|l|l|}
\hline Indicators & 20th century education & 21st century lifelong learning \\
\hline Objectives & $\begin{array}{l}\text { Education sets narrow } \\
\text { academic objectives and } \\
\text { targets and works to achieve } \\
\text { these in the present. }\end{array}$ & $\begin{array}{l}\text { The concept of lifelong learning } \\
\text { not only works to achieve } \\
\text { present targets but also to } \\
\text { impart future long term values } \\
\text { and attitudes to learning. For } \\
\text { this purpose; it is necessary } \\
\text { that curriculums deal with life } \\
\text { skills more and the link between } \\
\text { school and life and the } \\
\text { community between industry } \\
\text { and society have to be widener. }\end{array}$ \\
\hline Relationship with industry & $\begin{array}{l}\text { There is rudimentary short term } \\
\text { business plan usually around } \\
\text { academic matters and little } \\
\text { effort is made to keep every } \\
\text { stakeholder informed and on- } \\
\text { side. }\end{array}$ & $\begin{array}{l}\text { There is a full written } \\
\text { organizational strategy which is } \\
\text { available to all. This strategy } \\
\text { plan develops the school into } \\
\text { lifelong learning and covers the } \\
\text { all aspects of the school's } \\
\text { activity. In this aspect in order } \\
\text { to bring change in education } \\
\text { concept, it is necessary to } \\
\text { develop longer term school } \\
\text { business plan and make it } \\
\text { available to all. It is also }\end{array}$ \\
\hline
\end{tabular}


IJASOS- International E-Journal of Advances in Social Sciences, Vol. V, Issue 13, April 2019

\begin{tabular}{|c|c|c|}
\hline & & $\begin{array}{l}\text { necessary to create proactive } \\
\text { information strategies to bring } \\
\text { all stakeholders on-side. }\end{array}$ \\
\hline In-service training of teachers & $\begin{array}{l}\text { Some teachers go on } \\
\text { educational courses according } \\
\text { to their needs or desires and } \\
\text { there are occasional seminars } \\
\text { in schools only for teachers. }\end{array}$ & $\begin{array}{l}\text { Every person in the school has } \\
\text { a continuous improvement plan } \\
\text { for academic and personal skill } \\
\text { embedded into the } \\
\text { management system and as a } \\
\text { part they are related to the } \\
\text { school development plan. For } \\
\text { this purpose; it is necessary } \\
\text { that not only students but also } \\
\text { teachers and admin staff } \\
\text { develop written continuous } \\
\text { improvement plans for } \\
\text { academic and personal } \\
\text { development of pupils and it } \\
\text { should be extended these to } \\
\text { parents and community. }\end{array}$ \\
\hline Role of the teacher & $\begin{array}{l}\text { Teachers are the only human } \\
\text { resource for curriculum delivery } \\
\text { and other resources are } \\
\text { supplied from local government } \\
\text { and school events. }\end{array}$ & $\begin{array}{l}\text { It is objected to add human } \\
\text { resource by tapping into skills, } \\
\text { talents and knowledge of } \\
\text { governors, parents and } \\
\text { everyone in the community by } \\
\text { exploring funding. In order to do } \\
\text { this, besides the human and } \\
\text { other resources in the } \\
\text { community it is necessary to } \\
\text { use innovative strategies to } \\
\text { involve the community in school } \\
\text { development. }\end{array}$ \\
\hline Curriculum & $\begin{array}{l}\text { The curriculums are based on } \\
\text { discrete subjects and they are } \\
\text { assessed on memorizations of } \\
\text { facts with fail pass philosophy. }\end{array}$ & $\begin{array}{l}\text { The curriculum is based on } \\
\text { skills and knowledge, the } \\
\text { enhancement of self- esteem } \\
\text { and the acceptance of lifelong } \\
\text { values. In this aspect the } \\
\text { examinations are done as } \\
\text { stocktaking part of the personal } \\
\text { learning process. In order to } \\
\text { change this concept, personal } \\
\text { skills development has to be } \\
\text { incorporated into the } \\
\text { curriculum. Besides, the Notion } \\
\text { of failure should be taken out of } \\
\text { the system and replaced with } \\
\text { the strategies for improving } \\
\text { personal self-esteem. }\end{array}$ \\
\hline Support services & $\begin{array}{l}\text { The teachers are overworked } \\
\text { and sparse support service is } \\
\text { given to identify and solve } \\
\text { individual learning and social } \\
\text { problems. }\end{array}$ & $\begin{array}{l}\text { Guidance, support and } \\
\text { counseling systems are } \\
\text { available for all learners and } \\
\text { their families. The social } \\
\text { problems are identified rapidly } \\
\text { and there are rapid solutions for } \\
\text { learning and social problems. In } \\
\text { order to eliminate this }\end{array}$ \\
\hline
\end{tabular}




\begin{tabular}{|c|c|c|}
\hline & & $\begin{array}{l}\text { difference, it is necessary to } \\
\text { introduce individual learning } \\
\text { guidance systems for all pupils } \\
\text { frequently and the resources } \\
\text { like mentors should be used in } \\
\text { the school and community. The } \\
\text { families should be involved the } \\
\text { system and rapid response } \\
\text { system should be initiated. }\end{array}$ \\
\hline Evaluation & $\begin{array}{l}\text { The curriculum and schools are } \\
\text { based on examination success. } \\
\text { The social curriculum dealt with } \\
\text { an ad hoc basis. There are } \\
\text { some special and community } \\
\text { programs. }\end{array}$ & $\begin{array}{l}\text { It looks outward to the world } \\
\text { and it learns by contributing to } \\
\text { the community in which it } \\
\text { exists. A strong social } \\
\text { curriculum is created to } \\
\text { promote a sense of tolerance } \\
\text { and understanding of different } \\
\text { races, creeds and cultures. In } \\
\text { order to enhance the tolerance } \\
\text { and understanding in and out of } \\
\text { school, an active social } \\
\text { curriculum should be } \\
\text { introduced. Internet Networks } \\
\text { should be used in projects to } \\
\text { link pupils to other pupils } \\
\text { throughout the world. }\end{array}$ \\
\hline $\begin{array}{l}\text { Instruction methods and } \\
\text { techniques }\end{array}$ & $\begin{array}{l}\text { Teacher has a role of passer of } \\
\text { information through didactic } \\
\text { teaching methods using chalk, } \\
\text { talk and paper exercises. }\end{array}$ & $\begin{array}{l}\text { The teacher has a role of } \\
\text { developer of learning skills } \\
\text { using motivational power of the } \\
\text { individualized active learning } \\
\text { programmes like ICT, } \\
\text { multimedia and Networks. With } \\
\text { the aim of achieving this system } \\
\text { the teachers should be trained } \\
\text { in the many uses of technology } \\
\text { as learning tools. ICT should be } \\
\text { heavily invested thorough } \\
\text { innovative programs with } \\
\text { industry. }\end{array}$ \\
\hline Relationship with parents & $\begin{array}{l}\text { The parents are invited to } \\
\text { school to discuss the child's } \\
\text { progress once a term and there } \\
\text { are occasional public } \\
\text { information meetings. }\end{array}$ & $\begin{array}{l}\text { It is objected to involve the } \\
\text { family in to the life of the school } \\
\text { through increased homeschool } \\
\text { cooperation and to develop } \\
\text { their awareness about active } \\
\text { participation in school events. } \\
\text { So they play an active role in } \\
\text { the life of school. For this } \\
\text { purpose a family participation } \\
\text { guide outlining all the things } \\
\text { parents can do for the school } \\
\text { should be written. To establish } \\
\text { a contact with the parents an e- } \\
\text { mail line can be opened. }\end{array}$ \\
\hline School activities & $\begin{array}{l}\text { There is only one show or play } \\
\text { once a year and the actives out } \\
\text { of school are led by only }\end{array}$ & $\begin{array}{l}\text { It is possible to enhance the } \\
\text { confidence, creativity and the } \\
\text { cultural vision of staff, parents, }\end{array}$ \\
\hline
\end{tabular}




\begin{tabular}{|l|l|l|}
\hline & $\begin{array}{l}\text { enthusiastic teachers. } \\
\text { Sometimes there are Annual } \\
\text { School Fair and Presentation } \\
\text { Days. }\end{array}$ & $\begin{array}{l}\text { children and community through } \\
\text { a wide range of extra-curricular } \\
\text { activities. For this reason, an } \\
\text { impressive program of school } \\
\text { societies, out of school } \\
\text { activities, cultures, events } \\
\text { should be established and } \\
\text { involve the community where is } \\
\text { appropriate. }\end{array}$ \\
\hline Vision of school & $\begin{array}{l}\text { It is concentrated on academic } \\
\text { and personal success of all } \\
\text { pupils as a means of enhancing } \\
\text { the school's reputation and } \\
\text { satisfying society's needs. } \\
\text { Besides the public is invited to } \\
\text { share it. For this reason the } \\
\text { school should be marketed } \\
\text { strongly. It is important to } \\
\text { emphasize the positive learning } \\
\text { academic achievers in order } \\
\text { enhance attractiveness to } \\
\text { parents through position in } \\
\text { league tables. } \\
\text { staff and the community at } \\
\text { large. The school should create } \\
\text { its own league table of all round } \\
\text { achievement. }\end{array}$ \\
\hline
\end{tabular}

Lifelong learning means „continuous development and improvement of the knowledge and skills needed for employment and personal fulfillment through formal and informal learning opportunities" based on the four pillars of education for the future (Table 2) encouraging "creativity, initiative and responsiveness in people thereby enabling them to show adaptability in postindustrial society through enhancing skills to: manage uncertainty; communicate across and within cultures, sub-cultures, families and communities; negotiate conflicts. The emphasis is on learning to learn and the ability to keep learning for a lifetime" (Chitiba, 2012b).

Main challenges for lifelong learning process are: inducement of informal learning opportunities; stimulation of self-motivated learning; acceptance of self-funded learning; stimulation of universal participation to the learning process. In lifelong learning the learner is at the core of the learning process (Table 3).

Table 2. The four pillars of education in the future (Chitiba, 2012b).

\begin{tabular}{|l|l|}
\hline Learning to know: & $\begin{array}{l}\text { mastering learning tools rather than acquisition of } \\
\text { structured knowledge }\end{array}$ \\
\hline Learning to do: & $\begin{array}{l}\text { equipping people for the types of work needed } \\
\text { now and the future including innovation and } \\
\text { adaptation of learning to future work } \\
\text { environments }\end{array}$ \\
\hline Learning to live together, and with others: & $\begin{array}{l}\text { peacefully resolving conflict, discovering other } \\
\text { people and their cultures, fostering community } \\
\text { capability, individual competence and capacity, } \\
\text { economic resilience, and social inclusion }\end{array}$ \\
\hline Learning to be: & $\begin{array}{l}\text { education contributing to a personal } \\
\text { development: mind and body, intelligence, } \\
\text { sensitivity, aesthetic appreciation and spirituality }\end{array}$ \\
\hline
\end{tabular}


Table 3. Life-long learners at the core of the learning process.According to Knapper and Cropley (2000) (Coúkun, Demirel, 2010a)

\begin{tabular}{|c|}
\hline Life-long learners \\
\hline plan their own learning \\
\hline assess their own learning \\
\hline are active rather than passive learners \\
\hline learn in both formal and informal settings \\
\hline learn from their peers, teachers, mentors etc. \\
\hline integrate knowledge from different subject areas when required \\
\hline use different learning strategies for different situations \\
\hline
\end{tabular}

Lifelong learning „not only includes acquiring each kind of knowledge, skill, and quality but also updating them" (Baris and Tosun, 2011b). Links between educational system, lifelong learning and academic research are "real and desirable” and transdisciplinary niches create „an enriched research environment” and could provide real solutions in educational process and foster lifelong learning (Canter and Brumar, 2011c). The most important reasons to apply lifelong learning are in the necessity gained skills to meet contemporary challenges and making easier access to education, as well as provision of flexibility.

Among the many challenges for lifelong learning in contemporary societies along with the most general ones as financial, demographic, technological, social, environmental and democratic, the following could be mentioned: „better bridging among levels and learning settings; considering the need to maintain skills throughout life; considering financial issues to bring the discourse more decisively into policy discussion, and exploring the social dimension of learning" (Laal and Laal, 2012c).

The relationship between lifelong learning and interactive technology is underlined in the notion that technology-based learning is a hot topic nowadays and lead to development of new educational technology addressing lifelong learning in terms of "acquiring and updating all kinds of abilities, interests, knowledge and qualifications from the pre-school years to postretirement" (Laal, 2011d). Linking lifelong learning to eportfolio (in terms of digital records of curriculum vitae, personal development and new acquisitions) will be much more crucial in near future (Baris and Tosun, 2011b) punting the following fields of relationship between both concepts: new technology, information society, new methods of learning and teaching.

Lifelong learning's advantages are considered in regard to adults' training opportunities and social inclusion contributing to the adaptation processes and quality of life. Discussing the most important impacts of lifelong learning on quality of life (Escuder-Mollon, 2012e) the following should have special attention: positive thinking, learning, memory and concentration, interpersonal relations, personal development (achievement and status in education, cognitive, social and practical personal competence, and performance - success, achievement, productivity), and self-determination (independence, desires, expectations, choices, preferences). It is important to set in the proper way the training in respect to learning content, leaning environment, pedagogical approaches, etc. assuring active learning.

Table 4. Lifelong learning in different age periods (Laal, 2011d)

\begin{tabular}{|c|c|}
\hline Age 0-5 years & $\begin{array}{c}\text { Learning provides a foundation for future learning } \\
\text { habits and talents The age period with the } \\
\text { highest amount of informal learning }\end{array}$ \\
\hline Age 6-24 years & $\begin{array}{c}\text { Learning primarily takes place in educational } \\
\text { institutions - from primary and secondary to } \\
\text { tertiary levels. } \\
\text { Family life, social organizations, religious } \\
\text { institutions, and mass media have a role in }\end{array}$ \\
\hline
\end{tabular}


IJASOS- International E-Journal of Advances in Social Sciences, Vol. V, Issue 13, April 2019

\begin{tabular}{|c|c|}
\hline Age 25-60 years & learning during this time. \\
\hline Age 60+ years & $\begin{array}{c}\text { Learning informally through the use of } \\
\text { instructional media, mostly from occupations, } \\
\text { work-places, colleagues, touring, mass media, } \\
\text { information technologies, environment and } \\
\text { nature. } \\
\text { Learning from experiences and problem solving. } \\
\text { Need of continuous development of intellect, } \\
\text { capability and integrity. }\end{array}$ \\
\hline & $\begin{array}{c}\text { Learning from activities suitable to age e.g. art, } \\
\text { music, sports for the elderly, handicrafts and } \\
\text { social work. } \\
\text { Voluntary work in community organizations, clubs } \\
\text { and associations }\end{array}$ \\
\hline
\end{tabular}

In comparison to traditional learning, e-learning provides certain advantages as "reduced time for getting in touch with the source of learning, flexibility of learning schedule which lacks the classic on campus classes, less costs for the participant due to the fact that the study does not involve travelling, accommodation" (Pamfilie et al., 2012f). E-learning could be an effective and efficient alternative for continuous learning if virtual platforms have proper design and content according to cognitive and cultural characteristics of target learners (Pamfilie et al., 2012f). Thus, e-learning could provide the needed flexibility and accessibility for population in mountain regions if relevant basic knowledge and skills, as well as wish, are available, especially considering different people of different ages and understandings.

Lifelong learning considers the demand for and the supply of learning opportunities as part of „a connected system covering the whole lifecycle" offering a systematic view and emphasizing "the centrality of the learner" and the need for initiatives that „cater for the diversity of learner needs”, thus representing the shift of attention from the supply of learning to the demand side (Chitiba, 2012b). It is focused on the motivation to learn "and draws attention to self-paced and self-directed learning and it stresses the multiple objectives of education policy, which include economic, social or cultural outcomes; personal development, and citizenship" (Chitiba, 2012b). In the context of lifelong learning, the importance of career education has new dimensions bearing in mind that social integration is an active and lifelong process outlining the major purpose of education as preparation for life, thus changing the vision of educational content and imposing the need of considerations in the field of career planning. Barriers to lifelong learning could be economic, personal, social, foundational, technological, access, and motivational inextricably linked to one another (Table 5) (Laal, 2011e).

Table 5. Barriers to lifelong learning

\begin{tabular}{|c|c|}
\hline Structural barriers & $\begin{array}{c}\text { lack of appropriate education or training } \\
\text { opportunities, constraints of the benefit system }\end{array}$ \\
\hline Physical and material barriers & $\begin{array}{c}\text { costs of learning (direct - fees, and indirect - } \\
\text { transport, books, equipment, childcare), lack of } \\
\text { time, lack of information, geographical }\end{array}$ \\
\hline Attitudinal barriers & $\begin{array}{c}\text { negative attitudes to learning, lack of confidence } \\
\text { or lack of motivation }\end{array}$ \\
\hline
\end{tabular}

The elements needed to develop lifelong learning in a society are identified as follows: Partnership working; Insight into the demand for learning in the knowledge-based society; Adequate resourcing; Facilitating access to learning opportunities; Creating a learning culture and striving for excellence (Laal, 2011d).

Eight key teachers' competencies necessary for lifelong learning are outlined and explained: cognitive skills, self-esteem, problem solving, and application of modern ICT, information, mathematical and language literacy, and ability of empirical research (Ionela, 2012a). 
Lifelong learning is expected to "deliver competence development and labor market-related qualifications within and outside enterprises as part of human resource development to sustain economic growth" and "to contribute to the maintenance of democratic values and institutions, and to societal and personal development, as well as reducing development gaps between rural and urban areas" (Stanef et al., 2012f). Adaptation of lifelong learning approaches in national educational systems has important implications recognizing education in all forms. The relevant frameworks (legislative, governance, financial, institutional, learning, informational, qualifications and regulatory) should be created in national policy development in order to engage different communities in learning, as well as collateral policies in related areas as „employment, welfare, rural development and poverty reduction and monitoring and evaluation of policy impact across many ministries and agencies in order to reduce development gaps between rural and urban areas" (Stanef et al., 2012f). Among the main challenges before the humanity in the 21st century are educational and capacity building problems interlinked to globalization processes and information society development imposing the permanent existence of an educational environment and learning skills in times when information is rendered along with the general resources of well-being and sustainable development of future generations? Thus, it is not any more important to know all but to have skills to obtain information and deal with it. That is a big challenge to society and educational systems shifting to assurance of continuity in learning and building learning capacities, i.e. accenting abilities of self-learning.

Discussing „emergencies in lifelong learning”, it is stated that early dropout of formal education endangering economic and social security could find possible solutions in "continuing education, reflections and practices on local, national, regional and global scale" supported by the flagship initiatives of Europe 2020 Strategy within employment, social affairs and inclusion field (Bostan, 2014a).

A study of efforts by 15 countries to develop lifelong learning through reform of qualifications systems reveals 9 broad policy responses that other countries can draw on to develop and refine their policies on lifelong learning (Table 6) (Gelin, 2004 cited by Bidokht, 2011). The concept could be put into practice through new policies and strategies implementing flexible frameworks, innovative pedagogical approaches, new forms of assessments and institutional collaboration (Chitiba, 2012b).

Table 6. Policy responses to develop and define lifelong learning policies.

\begin{tabular}{|c|c|}
\hline 1. & Increased flexibility and responsiveness \\
\hline 2. & Motivating young people to learn \\
\hline 3. & Linking education and work \\
\hline 4. & Facilitating open access to qualifications \\
\hline 5. & Diversifying assessment processes \\
\hline 6. & Making qualifications progressive \\
\hline 7. & Making the qualifications system transparent \\
\hline 8. & Reviewing funding and increasing efficiency \\
\hline 9. & Better managing the qualifications system \\
\hline
\end{tabular}

Considering that in the Europe 2020 strategy three priorities are underlined: „Smart growth - developing an economy based on knowledge and innovation, Sustainable growth - promoting a more resource efficient, greener and more competitive economy and Inclusive growth - fostering a high employment economy delivering economic, social and territorial cohesion", it is concluded that sustainable development depends on affordable permanent education (Oprean et al., 2011f).

In the European Union, lifelong learning became the central part of educational policies in the context of struggles for a knowledge-based society and the importance of developing more competitive lifelong learning strategies in national educational systems will be more and more essential for a successful governmental policy (Lazar, Lazar, 2012g). It is very important to think about educational policies "able to increase beneficial effects both for individuals and for societies, to solve and avoid from cultural, social and economic disadvantages and to give a significant contribution to cooperating and social cohesion and stability" 
(Aleandri, Girotti, 2012h).

One of the four strategic objectives for the ET 2020 framework is making lifelong learning and mobility a reality and one of the major issues in putting it into practice is the educational system of each country which „is not yet prepared to develop lifelong learning competences” (Canter and Brumar, 2011c). Studentcentered and competence-based approaches, as well as transdisciplinary research and integrated knowledge, are big challenges to Bulgarian educational system too.

National strategy for lifelong learning 2014-2020 of the Republic of Bulgaria sets out the strategic framework of the state policy in education and training during the next program period according to the global goals put on the European level for smart, inclusive and sustainable growth as a response to all emerging challenges in regards to the social inclusion and economic growth. It accepts the definition of lifelong learning, as used in the EC Memorandum on lifelong learning (2000): „all purposeful learning activity, undertaken on an ongoing basis with the aim of improving knowledge, skills and competence", and covers all forms of education, training and learning outlining content, forms, environment and interactions among all the parties: learners; training providers; employers, trade organizations, labor unions, civil society organizations; regions, municipalities and local communities; governmental bodies as ministries and agencies, etc. according to the new scope of learning in conditions of quality assurance, transparency and comparability. Lifelong learning is targeted as a guiding principle in the supply of education and training in the national context (Table $7 \& 8$ ).

Table 7. Principles in the implementation of the National strategy for lifelong learning 2014-2020.

\begin{tabular}{|l|l|}
\hline Principle & \multicolumn{1}{|c|}{ Short description } \\
\hline Quality & $\begin{array}{l}\text { transforming lifelong learning into a factor for the } \\
\text { success and competitiveness of the citizenry, the } \\
\text { institutions, and organizations by providing the } \\
\text { conditions to achieve higher educational } \\
\text { objectives }\end{array}$ \\
\hline Equality and diversity & $\begin{array}{l}\text { ensuring equal opportunities for all individual and } \\
\text { collective stakeholders to exercise their rights } \\
\text { and duties arising from their participation in } \\
\text { various and multiple forms of lifelong learning, } \\
\text { which take place in diverse socio-economic } \\
\text { contexts }\end{array}$ \\
\hline Decentralization & $\begin{array}{l}\text { transfer of powers and resources from central } \\
\text { government bodies and public institutions to the } \\
\text { regional administrations, the municipalities, the } \\
\text { setups of social partners, the non-governmental } \\
\text { organizations, etc., and also to associations of } \\
\text { training providers in order to ensure the access } \\
\text { to lifelong learning activities for various target } \\
\text { groups and specific participants }\end{array}$ \\
\hline Flexibility & $\begin{array}{l}\text { conduct of consultation processes at various } \\
\text { levels, proactive dialogue and allocation of the } \\
\text { rights, duties, and risks among all stakeholders in } \\
\text { order to achieve the strategic objectives and } \\
\text { priorities of the lifelong learning policy through } \\
\text { implementation of the specific measures } \\
\text { scheduled for the impact areas }\end{array}$ \\
\hline Cooperation & $\begin{array}{l}\text { enhancement of the opportunities for monitoring } \\
\text { and measuring the education objectives }\end{array}$ \\
\hline $\begin{array}{l}\text { preparedness of the stakeholders to respond, } \\
\text { upon occurrence/ascertainment of unforeseen } \\
\text { social and socio-economic processes, through } \\
\text { expansion of the earmarked objectives and }\end{array}$ \\
\hline
\end{tabular}


IJASOS- International E-Journal of Advances in Social Sciences, Vol. V, Issue 13, April 2019

action

Table 8. National strategy for lifelong learning 2014-2020 strategic priorities.

\begin{tabular}{|c|c|}
\hline Priorities & Impact areas \\
\hline $\begin{array}{l}\text { - A step forward to a new educational approach } \\
\text { and innovations in education and training; } \\
\text { - Increasing the quality of education and } \\
\text { training; } \\
\text { - Ensuring the educational environment for } \\
\text { equal access to lifelong learning and for active } \\
\text { social inclusion and active citizen participation; } \\
\text { - Promoting education and training aligned to } \\
\text { the needs of the economy and changes on the } \\
\text { labour market. }\end{array}$ & $\begin{array}{l}\text { - Ensuring the conditions for transition to a } \\
\text { functioning system for lifelong learning. } \\
\text { - Ensuring the conditions for expanding the } \\
\text { scope and enhancing the quality of preschool } \\
\text { education and training; } \\
\text { - Applying a comprehensive approach to } \\
\text { enhancing the educational achievements and } \\
\text { reducing the share of early school leavers; } \\
\text { - Enhancing the quality of school education and } \\
\text { training towards attainment of the key } \\
\text { competences, improving the learners' } \\
\text { achievements and personality development; } \\
\text { - Increasing the attractiveness and improving } \\
\text { the quality of vocational education and training to } \\
\text { ensure employment and competitiveness; } \\
\text { - Modernizing the higher education; } \\
\text { - Development of opportunities for non-formal } \\
\text { and informal learning for personal and } \\
\text { professional progress. New opportunities for } \\
\text { good quality of life following the working career's } \\
\text { end; } \\
\text { - Coordinating the interaction among } \\
\text { stakeholders in the implementation of the lifelong } \\
\text { learning policy. }\end{array}$ \\
\hline
\end{tabular}

Lifelong learning is in the basis of the reforms on different levels because of its significance for assurance of quality of life and social security, the links to globalization and technological changes and economic opportunities (Terziev, Arabska, 2015a). Establishing the right educational policies based on preliminary needs' analyses and providing equal opportunities is part of effective strategies of overcoming unemployment and contributing to social cohesion and stability. The harmonization of European, national and local strategies is necessary for provision of efficiency, assurance of funding and resources and longterm effects.

Table 9. Development of lifelong learning

Lifelong learning encouragement prerequisite

- Recognition of non-formal and informal learning;

- Encouragement of vocational training;

- Development of trainers skills;

- Creating culture of learning through increased learning opportunities, improving access and participation, stimulating learning demand;

- Inclusion of a broader scope of learners in respect to age, occupation, educational and professional background, etc.;

- Partnership approach - collaboration of all stakeholders in planning, implementation, funding, resources allocation, etc.; 
- Communication and coordination;

- Developing mechanisms for quality assurance, evaluation and monitoring;

- Continuous improvement and renewal of policies and system.

There is a need of measuring whether current education and qualification system answers the needs of individuals and organizations, as well as how to apply best lifelong learning in order to assure improvements in qualifications and recognition. The outcomes should be measured as quality skills giving competitive advantages to learners and making them adaptable and mobile. However, all the interventions should be carefully analyzed before entering into force according to specific characteristics of some regions and their population in connection to the existing culture and understandings. The introduction of the culture of lifelong learning would not be an easy and fast process. Significant efforts in motivation activities should be put and it should embrace all the parties: state through regulatory requirements, policies, strategies and specific support; business - actively participating, determining needs and providing support; educational and training institutions - building capacities and assuring inclusion; potential learners - willing to change (Terziev, Arabska, 2015a).

Development of lifelong learning in less favored regions (as mountain) is viewed as an opportunity for capacity building activities and needs a specifically targeted lifelong learning application policy based on the broad participatory approach and using available resources and modern information and communication technology (Terzie, Arabska, 2015a). It should provide implications for solutions of the main problems connected to access, as well as teachers' skills of lifelong learning approaches, especially in curricula development based on enhancement of personal skills, and further evaluation and quality control mechanisms. Networking as a collaborative learning opportunity could provide the needed flexible framework of learning anytime at anyplace concerning individual needs and learning abilities. The creation of a new learning culture is the first necessary prerequisite in motivation activities and making learning more accessible in mountain regions in the country. The application of such a strategy will need support of the institutional system (educational and training institutions, state, non-governmental and business organizations) and relevant infrastructure on regional level. Development of partnerships should be substantiated by the identification of the needs (both of learners and the labor market) and relevant resources respecting cultural, ethnic and linguistic diversities (Terziev, Georgiev, 2018a-d; Terziev, Banabakova, Georgiev, 2018c-e; Terziev, Banabakova, Georgiev, 2018e-o; Dimitrova, Georgiev, 2017a-b; Terziev, Banabakova, Arabska, 2018p; Terziev, Arabska, Banabakova, Kovalyov, 2018q; Terziev, Arabska, Banabakova, Ignatova, Kovalyov, 2018r; Terziev, Arabska, Banabakova, 2018s; Terziev, 2016a; Terziev, 2017c; Terziev, Radev, Arabska, Dimitrovski, 2017d; Terziev, 2017e; Bogdanova, 2017f; Bogdanova, 2016b; Bogdanova, 2016c; Bogdanova, 2015b; Bogdanova, 2015c; Bogdanova, 2012i; Bogdanova, ParashkevovaVelikova, 2015d; Parashkevova-Velikova, Bogdanova, 2016d).

Table 10. Key issues and there linkages in lifelong learning development

\begin{tabular}{|c|l|l|c|c|}
\hline \multicolumn{5}{|c|}{ European and national regulatory framework } \\
\hline $\begin{array}{c}\text { Strategic } \\
\text { partnerships }\end{array}$ & Teaching & Learning & $\begin{array}{c}\text { Administration and } \\
\text { support systems }\end{array}$ & $\begin{array}{c}\text { Monitoring and control } \\
\text { system }\end{array}$ \\
\hline Relationships & \multicolumn{2}{|c|}{ Roles of participants } & Access & Quality assurance \\
\hline \multicolumn{3}{|c|}{ Policies encouraging lifelong learning in disadvantaged regions } \\
\hline
\end{tabular}

Table 11. Mechanisms fostering lifelong learning

\begin{tabular}{|c|c|c|c|}
\hline $\begin{array}{c}\text { Communication and } \\
\text { coordination }\end{array}$ & Recognition of skills & Employability & $\begin{array}{c}\text { Quality assurance } \\
\text { system }\end{array}$ \\
\cline { 1 - 3 } Pedagogical innovation & $\begin{array}{c}\text { Qualifications } \\
\text { framework }\end{array}$ & $\begin{array}{c}\text { Flexibility in learning } \\
\text { programs }\end{array}$ & \\
\hline
\end{tabular}


IJASOS- International E-Journal of Advances in Social Sciences, Vol. V, Issue 13, April 2019

\begin{tabular}{|c|c|c|}
\hline Learning pathways & Validation procedures & Needs'analyses \\
\hline \multicolumn{2}{|c|}{ Learning outcomes } \\
\hline \multicolumn{2}{|c|}{ Participatory approaches } \\
\hline
\end{tabular}

\section{CONCLUSION}

Development of lifelong learning programs is important because of the opportunities they provide for assuring employment, higher quality of life and social inclusion, as well as for economic growth and community development as a whole. Lifelong learning policies are needed because permanent trainings lead to acquisition of valuable skills providing competitive advantages of individuals on the labor market in conditions of globalization of economic and social life, fast technological changes and increase in the importance of knowledge in economy.

Discussing concrete measures of support in lifelong learning in the country, some common aims could be identified concerning also the national education and qualification system: improving communication and cooperation between state, educational institutions, business organizations and society, adaptation of training to labor market demand and improving training programs on different levels and types, motivation for lifelong learning and career development. Educational measures should be connected to labor market measures, social and fiscal policies in order to increase employment, labor efficiency and motivation for selfimprovement.

\section{REFERENCE LIST}

Lonela, A. M. (2012a). The role of lifelong learning in the growth of employment and labour efficiency. // The case of Romania. Procedia - Social and Behavioral Sciences 46, pp. 4399-4403.

Demirel, M. (2009a). Lifelong learning and schools in the twenty-first century. Procedia Social and Behavioral Sciences 1, pp 1709-1716.

Chibiba, C. A. (2012b). Lifelong learning challenges and opportunities for traditional universities. Procedia Social and Behavioral Sciences 46, pp. 1943- 1947.

Jovanova-Mitkovska, S., Hristovska, D. (2011a). Contemporary teacher and core competences for lifelong learning. Procedia - Social and Behavioral Sciences 28, pp. 573-578.

Baris, M. F., Tosun, N. (2011b). E-portfolio in Lifelong Learning Applications. // Procedia - Social and Behavioral Sciences 28, pp.522-525.

Canter, M., Brumar, C. I. (2011c). Transdisciplinary niches fostering Lifelong Learning. Procedia - Social and Behavioral Sciences 28, pp. 636-639.

Laal, M., Laal, A. (2012c). Challenges for lifelong learning. // Procedia - Social and Behavioral Sciences 47, pp. 1539-1544.

Laal, M., Laal, A. (2012d). Lifelong learning; elements. // Procedia - Social and Behavioral Sciences 47, pp. 1562-1566.

Escuder-Mollon, P. (2012e). Modelling the impact of lifelong learning on senior citizens' quality of life. // Procedia - Social and Behavioral Sciences 46, pp. 2339-2346.

Laal, M. (2011d). Lifelong learning: What does it mean? Procedia - Social and Behavioral Sciences 28, pp. 470-474.

Pamfilie, R., Onete, B., Maiorescu, I., Pleşea, D. (2012f). E-learning as an alternative solution for sustainable lifelong education. Procedia - Social and Behavioral Sciences 46, pp. 4026-4030.

Laal, M. (2011e). Barriers to lifelong learning. // Procedia - Social and Behavioral Sciences 28, pp. 612-615.

Stanef, M. R., Manole, A. M., Militaru, M. (2012g). Lifelong learning a way to reduce development gaps between rural and urban areas. // Procedia - Social and Behavioral Sciences 46, pp. 4508-4512. 
IJASOS- International E-Journal of Advances in Social Sciences, Vol. V, Issue 13, April 2019

Bostan, C.G. (2014a). Emergencies in lifelong learning. // Procedia - Social and Behavioral Sciences 142, pp. 268-273.

Oprean, C., Brumar, C. I., CanŃer, M., Bărbat, B. E. (2011f). Sustainable development: e-teaching (now) for lifelong e-Learning. // Procedia - Social and Behavioral Sciences 30, pp. 988-992.

Lazăr, I., Lazăr, L. (2012h). Considerations on the implementation of the lifelong learning initiative in the European Union. // Procedia - Social and Behavioral Sciences 46, pp. 2533-2536.

Aleandri, G., Girotti, L. (2012i). Lifelong learning and training: a never ending challenge and choice for educational system. // Procedia - Social and Behavioral Sciences 46, pp. 1406-1412.

Terziev, V., Arabska, E. (2015a). Contemporary challenges of building competences through life-long learning in mountain regions. Sustainable mountain regions: make them work, May 2015, International Scientific Conference Proceedings, pp. 110-116.

Coúkun, Y. D., Demirel, M. (2010a). Lifelong learning tendency scale: the study of validity and reliability. // Procedia Social and Behavioral Sciences 5, pp. 2343-2350.

Terziev, V., Georgiev, M. (2018a). A strategic framework for the development of social entrepreneurship in Bulgaria. // Knowledge - International Journal, August 2018, Institute of Knowledge Management, Skopje, Macedonia, 25, 2018, N1, pp. 23-34, ISSN 1857-923X (for e-version), ISSN 2545 - 4439 (for printed version).

Terziev, V., Georgiev, M. (2018b). Support for the development of social entrepreneurship in Bulgaria. // Knowledge - International Journal, September 2018, Institute of Knowledge Management, Skopje, Macedonia, 26, 2018, N1, pp.57-74, ISSN 1857-923X (for e-version), ISSN 2545 - 4439 (for printed version).

Terziev, V., Georgiev, M. (2018c). Characteristics of the Social Assistance System. // Sbornik dokladi ot godishna universitetska nauchna konferentsiya 14-15 yuni 2018 g., Elektronno izdanie, NVU Vasil Levski- Veliko Tarnovo, Veliko Tarnovo, 2018, str. 959-969, ISBN 978-619-7246-20-9 (online e-book), ISSN 2367-7481 (Терзиев, В., Георгиев, М. Характеристики на системата за социално подпомагане. // Сборник доклади от годишна университетска научна конференция 14-15 юни 2018 г., Електронно издание, НВУ Васил Левски- Велико Търново, Велико Търново, 2018, стр. 959-969, ISBN 978-619-7246-20-9 (online e-book), ISSN 2367-7481).

Terziev, V., Georgiev, M. (2018d). Social Protection of Vulnerable Populations in Bulgaria. // Sbornik dokladi ot godishna universitetska nauchna konferentsiya 14-15 yuni 2018 g., Elektronno izdanie, NVU Vasil Levski- Veliko Tarnovo, Veliko Tarnovo, 2018, str. 970-975, ISBN 978-619-7246-20-9 (online e-book), ISSN 2367-7481 (Терзиев, В., Георгиев, М. Социална защита на уязвимите групи от населението в България. // Сборник доклади от годишна университетска научна конференция 14-15 юни 2018 г., Електронно издание, НВУ Васил Левски- Велико Търново, Велико Търново, 2018, стр. 970-975, ISBN 978-619-7246-20-9 (online e-book), ISSN 2367-7481).

Terziev, V., Banabakova, V., Georgiev, M. (2018e). Modern dimensions of social policies. // International journal scientific papers Vol 23.4 Promoted in Budva, Montenegro 24-27.05.2018, IKM - Skopje, 23, 2018, N 4, pp. 935-944, ISSN 1857-923X (for e-version) ISSN 2545- 4439 (for printed version).

Terziev, V., Banabakova, V., Georgiev, M. (2018f). Social support as part of social policy. // International journal scientific papers Vol 23.4 Promoted in Budva, Montenegro 24-27.05.2018, IKM - Skopje, 23, 2018, N 4, pp. 973-980, ISSN 1857-923X (for e-version) ISSN 2545 - 4439 (for printed version).

Terziev, V., Banabakova, V., Georgiev, M. (2018g). Structure of the social welfare system in Bulgaria. // International journal scientific papers Vol 23.4 Promoted in Budva, Montenegro 24-27.05.2018, IKM Skopje, 23, 2018, N 4, pp. 1275-1281, ISSN 1857-923X (for e-version) ISSN 2545 - 4439 (for printed version).

Terziev, V., Banabakova, V., Georgiev, M. (2018h). Role and place of social programing in public governance. // Mizhnarodnoï naukovo-praktichnoï konferentsiï «Zabezpechennya stalogo rozvitku ekonomiki: problemi, mozhlivosti, perspektivi» (16-17 lyutogo 2018 roku, m. Uzhgorod), Ministerstvo osviti i nauki Ukraïni Uzhgorodsykiy natsionalyniy universitet, 2018, s.93-98, ISBN 978-966-916-488-9 (Terziev, V., Banabakova, V., Georgiev, M. Role and place of social programing in public governance. // Міжнародної науково-практичної конференції «Забезпечення сталого розвитку економіки: проблеми, можливості, перспективи» (16-17 лютого 2018 року, м. Ужгород), Міністерство освіти і науки України Ужгородський національний університет, 2018, с.93-98, ISBN 978-966-916-488-9). 
Terziev, V., Banabakova, V., Georgiev, M. (2018i). Social program as a product of social programming. // Mizhnarodnoï naukovo-praktichnoï konferentsiï «Zabezpechennya stalogo rozvitku ekonomiki: problemi, mozhlivosti, perspektivi» (16-17 lyutogo 2018 roku, m. Uzhgorod), Ministerstvo osviti i nauki Ukraïni Uzhgorodsykiy natsionalyniy universitet, 2018, s. 99-104, ISBN 978-966-916-488-9 (Terziev, V., Banabakova, V., Georgiev, M. Social program as a product of social programming. // Міжнародної науково-практичної конференції «Забезпечення сталого розвитку економіки: проблеми, можливості, перспективи» (16-17 лютого 2018 року, м. Ужгород), Міністерство освіти і науки України Ужгородський національний університет, 2018, с. 99-104, ISBN 978-966-916-488-9).

Terziev, V., Banabakova, V., Georgiev, M. (2018j). Social efficiency as a measure of social activities. // Mizhnarodnoï naukovo-praktichnoï konferentsiï «Zabezpechennya stalogo rozvitku ekonomiki: problemi, mozhlivosti, perspektivi» (16-17 lyutogo 2018 roku, m. Uzhgorod), Ministerstvo osviti i nauki Ukraïni Uzhgorodsykiy natsionalyniy universitet, 2018, s. 104-109, ISBN 978-966-916-488-9 (Terziev, V., Banabakova, V., Georgiev, M. Assessment of the effectiveness of social programing. // Міжнародної науково-практичної конфреренції «Забезпечення сталого розвитку економіки: проблеми, можливості, перспективи» (16-17 лютого 2018 року, м. Ужгород), Міністерство освіти і науки України Ужгородський національний університет, 2018, с. 110-115, ISBN 978-966-916-4889).

Terziev, V., Banabakova, V., Georgiev, M. (2018k). Social activity of human resource as a basis of effective social policy. // Mizhnarodnoï naukovo-praktichnoï konferentsiï «Zabezpechennya stalogo rozvitku ekonomiki: problemi, mozhlivosti, perspektivi» (16-17 lyutogo 2018 roku, m. Uzhgorod), Ministerstvo osviti i nauki Ukraïni Uzhgorodsykiy natsionalyniy universitet, 2018, s. 116-121, ISBN 978-966-916488-9 (Terziev, V., Banabakova, V., Georgiev, M. Social activity of human resource as a basis of effective social policy. // Міжнародної науково-практичної конфреренції «Забезпечення сталого розвитку економіки: проблеми, можливості, перспективи» (16-17 лютого 2018 року, м. Ужгород), Міністерство освіти і науки України Ужгородський національний університет, 2018, с. 116-121, ISBN 978-966-916-488-9).

Terziev, V., Banabakova, V., Georgiev, M. (2018I). Strategic advantages of an active social program. // Міжнародної науково-практичної конференції «Забезпечення сталого розвитку економіки: проблеми, можливості, перспективи» (16-17 лютого 2018 року, м. Ужгород), Міністерство освіти і науки України Ужгородський національний університет, 2018, с. 122-127, ISBN 978-966-916-4889 (Terziev, V., Banabakova, V., Georgiev, M. Strategic advantages of an active social program. // Міжнародної науково-практичної конфреренції «Забезпечення сталого розвитку економіки: проблеми, можливості, перспективи» (16-17 лютого 2018 року, м. Ужгород), Міністерство освіти і науки України Ужгородський національний університет, 2018, с. 122-127, ISBN 978-966-916-4889).

Terziev, V., Banabakova, V., Georgiev, M. (2018m). Assessment of the effectiveness of social programming. // Mizhnarodnoï naukovo-praktichnoï konferentsiï «Zabezpechennya stalogo rozvitku ekonomiki: problemi, mozhlivosti, perspektivi» (16-17 lyutogo 2018 roku, m. Uzhgorod), Ministerstvo osviti i nauki Ukraïni Uzhgorodsykiy natsionalyniy universitet, 2018, s. 127-131, ISBN 978-966-916-488-9 (Terziev, V., Banabakova, V., Georgiev, M. Assessment of the effectiveness of social programming. // Міжнародної науково-практичної конференції «Забезпечення сталого розвитку економіки: проблеми, можливості, перспективи» (16-17 лютого 2018 року, м. Ужгород), Міністерство освіти і науки України Ужгородський національний університет, 2018, с. 127-131, ISBN 978-966-916-4889).

Terziev, V., Banabakova, V., Georgiev, M. (2018n). The social program as a part of development strategies. // Mizhnarodnoï naukovo-praktichnoï konferentsiï «Zabezpechennya stalogo rozvitku ekonomiki: problemi, mozhlivosti, perspektivi» (16-17 lyutogo 2018 roku, m. Uzhgorod), Ministerstvo osviti i nauki Ukraïni Uzhgorodsykiy natsionalyniy universitet, 2018, s. 132-137, ISBN 978-966-916-488-9 (Terziev, V., Banabakova, V., Georgiev, M. The social program as a part of development strategies. // Міжнародної науково-практичної конфреренції «Забезпечення сталого розвитку економіки: проблеми, можливості, перспективи» (16-17 лютого 2018 року, м. Ужгород), Міністерство освіти і науки України Ужгородський національний університет, 2018, с. 132-137, ISBN 978-966-916-4889).

Terziev, V., Banabakova, V., Georgiev, M. (20180). Social programming as a possibility to increase social efficiency. // Mizhnarodnoï naukovo-praktichnoï konferentsiï «Zabezpechennya stalogo rozvitku ekonomiki: problemi, mozhlivosti, perspektivi» (16-17 lyutogo 2018 roku, m. Uzhgorod), Ministerstvo osviti i nauki Ukraïni Uzhgorodsykiy natsionalyniy universitet, 2018, s. 137-142, ISBN 978-966-916- 
488-9 (Terziev, V., Banabakova, V., Georgiev, M. Social programming as a possibility to increase social efficiency. // Міжнародної науково-практичної конференції «Забезпечення сталого розвитку економіки: проблеми, можливості, перспективи» (16-17 лютого 2018 року, м. Ужгород), Міністерство освіти і науки України Ужгородський національний університет, 2018, с. 137-142, ISBN 978-966-916-488-9).

Dimitrova, P., Georgiev, M. (2017a). Model of methodology for determining the needs of continuing vocationaltraining work specialists providing social services. // Innovatsii, tehnologii, nauka. Sbornik statey Mezhdunarodnoy nauchno - prakticheskoy konferentsii 25 yanvarya 2017 g., NITS Aeterna Permy, Chasty 4, 2017, s. 204-235, ISBN 978-5-906925-99-2, ISBN 978-5-00109-000-7 (Dimitrova, P., Georgiev M. Model of methodology for determining the needs of continuing vocationaltraining work specialists providing social services. // Инновации, технологии, наука. Сборник статей Международной научно - практической конференции 25 января 2017 г., НИЦ Аэтерна Пермь, Часть 4, 2017, с. 204-235, ISBN 978-5-906925-99-2, ISBN 978-5-00109-000-7).

Dimitrova, P., Georgiev, M. (2017b). Research, identification and monitoring of the needs of occupational training of social activities experts. // Innovatsii, tehnologii, nauka. Sbornik statey Mezhdunarodnoy nauchno - prakticheskoy konferentsii 25 yanvarya 2017 g., NITS Aeterna Permy, Chasty 4, 2017, s. 235-258, ISBN 978-5-906925-99-2, ISBN 978-5-00109-000-7 (Dimitrova, P., Georgiev M. Research, identification and monitoring of the needs of occupational training of social activities experts. // Инновации, технологии, наука. Сборник статей Международной научно - практической конфреренции 25 января 2017 г., НИЦ Аэтерна Пермь, Часть 4, 2017, с. 235-258, ISBN 978-5906925-99-2, ISBN 978-5-00109-000-7).

Terziev, V., Banabakova, V., Arabska, E. (2018p). The experience of the centres for provision of integrated employment and social assistance services in Bulgaria. // Upravlenie i Obrazovanie, Universitet "Prof. d-r Asen Zlatarov", Burgas, 14, 2018, N 1, str.5-14, ISSN 13126121. (Terziev, V., Banabakova, V., Arabska, E. The experience of the centres for provision of integrated employment and social assistance services in Bulgaria. // Управление и Образование, Университет “Проф. д-р Асен Златаров", Бургас, 14, 2018, N 1, стр.5-14, ISSN 13126121).

Terziev, V., Arabska, E., Banabakova, V., Kovalyov, E. (2018q). Bolgarsko-Rossiyskoe sotrudnichestvo v oblasti proektirovaniya i realizatsii mezhdunarodnayh setevayh obrazovatelynayh programm. // Sozdanie komfortnoy sreday sotsializatsii uchashtihsya, studentov i uchyonayh, Akademiya za inovatsii i ustoychivost - Plovdiv, Balgariya, 2018, str. 65-69, ISBN 978-619-7246-17-9 (print) ISBN 978-619-7246-18-6 (DVD). Терзиев, В., Арабска, Е., Банабакова, В. Ковалёв, Э. БолгарскоРоссийское сотрудничество в области проектирования и реализации международных сетевых образовательных программ. // Создание комфортной среды социализации учащихся, студентов и учёных, Академия за иновации и устойчивост - Пловдив, България, 2018, стр. 65-69, ISBN 978-619-7246-17-9 (print) ISBN 978-619-7246-18-6 (DVD).

Terziev, V., Arabska, E., Banabakova, V., Ignatova, M., Kovalyov, E. (2018r). Vliyanie tvorchestva G. V. Sviridova na kachestvo sotsializatsii studencheskoy molodyozhi. // Sozdanie komfortnoy sreday sotsializatsii uchashtihsya, studentov i uchyonayh, Akademiya za inovatsii i ustoychivost - Plovdiv, Balgariya, 2018, str. 71-80, ISBN 978-619-7246-17-9 (print) ISBN 978-619-7246-18-6 (DVD). Терзиев, В., Арабска, Е., Банабакова, В., Игнатова, М., Ковалёв, Э. Влияние творчества Г. В. Свиридова на качество социализации студенческой молодёжи. // Создание комфортной среды социализации учащихся, студентов и учёных, Академия за иновации и устойчивост - Пловдив, България, 2018, стр. 71-80, ISBN 978-619-7246-17-9 (print) ISBN 978-619-7246-18-6 (DVD).

Terziev, V., Arabska, E., Banabakova, V. (2018s). Sotsialyno-ekonomicheskoe polozhenie nezashtishtyonnayh sloyov naseleniya. // Sozdanie komfortnoy sreday sotsializatsii uchashtihsya, studentov i uchyonayh, Akademiya za inovatsii i ustoychivost - Plovdiv, Balgariya, 2018, str. 87-89, ISBN 978-619-7246-17-9 (print) ISBN 978-619-7246-18-6 (DVD). Терзиев, В., Арабска, E., Банабакова, В. Социально-экономическое положение незащищённых слоёв населения. // Создание комфортной среды социализации учащихся, студентов и учёных, Академия за иновации и устойчивост - Пловдив, България, 2018, стр. 87-89, ISBN 978-619-7246-17-9 (print) ISBN 978-619-7246-18-6 (DVD).

Terziev, Venelin. (2016a). Process of deinstitutionalization of children at risk in Bulgaria. // Fifth Annual International Research-to-Practice Conference «Early Childhood Care and Education» (ECCE 2016). 12-14 May, 2016, Lomonosov Moscow State University - MSU, Moscow, Russia, 2016, ISSN 23086408, pp.170-179. 
Terziev, Venelin. (2017c). Prevention and support to persons at risk of social marginalization. // Children \& Schools, 39, 2017, N 4(2), pp. 1139- 1150, ISSN 1532-8759, Source Normalized Impact per Paper (SNIP): 0.400 SCImago Journal Rank (SJR): 0.211 Impact factor: 1.086 5-Yr impact factor: 1.152 .

Terziev, V., Radev, D., Arabska, E., Dimitrovski, R. (2017d). Deinstitutionalisation of children as part of the development of social services in Bulgaria. // Twelfth international scientific conference Knowledge without borders, 31.3-2.4.2017, Vrnjacka Banja, Serbia, Institute of Knowledge Management, Skopje 16, 2017, N 1, ISSN 1857-923X, pp.19-28 .

Terziev, Venelin. (2017e). The system of social services in Bulgaria and the process of deinstitutionalisation of children. // Proceedings of the VII International Academic Congress "Fundamental and Applied Studies in EU and CIS Countries" (United Kingdom, Cambridge, England, 26-28 February 2017). Cambridge University Press, 7, 2017, ISBN: 978-0-875-83597-4, pp.338-351, Source Normalized Impact per Paper (SNIP): 5.192 SCImago Journal Rank (SJR): 5.186 Impact factor: 7.549.

Bogdanova, Margarita. (2017f). Predizvikatelstva pred upravlenieto na proekti v universitetite. Novite realnosti v upravlenieto : Sbornik s dokladi ot yubileyna mezhdunarodna nauchna konferentsiya po sluchay 50 godini katedra "Upravlenie i administratsiya" - Varna, 20-21 oktomvri 2017g. Nauka i ikonomika IU - Varna, 2017, str. 281-289, ISBN: 978-954-21-0947-1 (Богданова, Маргарита. Предизвикателства пред управлението на проекти в университетите. Новите реалности в управлението : Сборник с доклади от юбилейна международна научна конференция по случай 50 години катедра "Управление и администрация" - Варна, 20-21 октомври 2017г. Наука и икономика ИУ - Варна, 2017, стр. 281-289, ISBN: 978-954-21-0947-1).

Bogdanova, Margarita. (2016b). Akademichniyat kapitalizam i predizvikatelstvata pred universitetite. // Sbornik dokladi ot Godishna universitetska nauchna konferentsiya: Nauchno napravlenie „Sotsialni, stopanski i pravni nauki“- Veliko Tarnovo, 20-21 oktomvri 2016g. Veliko Tarnovo, NVU - Izd. kompleks, 7, 2016, str. 147-156, ISSN 1314-1937 (Богданова, Маргарита. Академичният капитализъм и предизвикателствата пред университетите. // Сборник доклади от Годишна университетска научна конференция: Научно направление „Социални, стопански и правни науки“- Велико Търново, 20-21 октомври 2016г. Велико Търново, НВУ - Изд. комплекс , 7, 2016, стр. 147-156, ISSN 1314-1937).

Bogdanova, Margarita. (2016c). Rolya na universitetite v obshtestvoto na znanieto. // Ikonomichesko blagosastoyanie chrez spodelyane na znaniya: Mezhdunarodna nauchna konferentsiya - Svishtov, 0910 noem. 2016 g., Al Tsenov, 2016, str. 414-419, ISBN: 978-954-23-1187-4 (Богданова, Маргарита. Роля на университетите в обществото на знанието. // Икономическо благосъстояние чрез споделяне на знания: Международна научна конференция - Свищов, 09-10 ноем. 2016 г., АИ Ценов, 2016, стр. 414-419, ISBN: 978-954-23-1187-4).

Bogdanova, Margarita. (2015b). Podhodi za satrudnichestvo mezhdu visshite uchilishta i biznesa. // Sotsialnite nauki i razvitieto na obshtestvoto - teoretichni i prakticheski izmereniya: Mezhdunarodna yubileyna nauchna konferentsiya - Svishtov, 30-31 oktomvri 2015g., Al Tsenov, 2015, str. 41-47, ISBN: 978-954-23-1093-8 (Богданова, Маргарита. Подходи за сътрудничество между висшите училища и бизнеса. // Социалните науки и развитието на обществото - теоретични и практически измерения: Международна юбилейна научна конференция - Свищов, 30-31 октомври 2015г., АИ Ценов, 2015, стр. 41-47, ISBN: 978-954-23-1093-8).

Bogdanova, Margarita. (2015c). Program management at the university science research. // Menedzhment sub'ektiv gospodaryuvannya: problemi ta perspektivi rozvitku : Zbirnik materialiv III Mizhnarodnoi naukovo-praktichnoi konferentsii - Zhitomir, 11-13 chervnya 2015 roku, Zhitomir, ZHDTU, 2015, pp. 157-160, ISBN: 978-966-683-449-5 (Bogdanova, Margarita. Program management at the university science research. // Менеджмент суб'єктів господарювання: проблеми та перспективи розвитку : Збірник матеріалів III Міжнародноі науково-практичноі конференціі - Житомир, 11-13 червня 2015 року, Житомир, ЖДТУ, 2015, рp. 157-160, ISBN: 978-966-683-449-5).

Bogdanova, Margarita. (2012i). Dobri praktiki v obuchenieto prez tseliya zhivot. // Chetvarta natsionalna konferentsiya s mezhdunarodno uchastie po elektronno obuchenie vav vissheto obrazovanie: Sbornik dokladi i rezyumeta - Svishtov, 11-13 May 2012g., Al Tsenov, 2012, str. 186-189, ISBN: 978-954-230747-1 (Богданова, Маргарита. Добри практики в обучението през целия живот. // Четвърта национална конференция с международно участие по електронно обучение във висшето образование: Сборник доклади и резюмета - Свищов, 11-13 май 2012г., АИ Ценов, 2012, стр. 186-189, ISBN: 978-954-23-0747-1). 
Bogdanova, M., Parashkevova-Velikova, E. (2015d). Integriranost na strategiite za nauchni izsledvaniya v planovite dokumenti na visshite uchilishta. // Biznes upravlenie, Svishtov, Balgariya, 4, 2015, str. 5-24, ISSN: 0861-6604 (Богданова, М., Парашкевова-Великова, Е. Интегрираност на стратегиите за научни изследвания в плановите документи на висшите училища. // Бизнес управление, Свищов, България, 4, 2015, стр. 5-24, ISSN: 0861-6604).

Parashkevova-Velikova, E., Bogdanova, M. (2016d). Model of strategic alignment in the universities. // Scientific Proceedings of the Scientific-Technical Union of Mechanical Engineering, 2016, 6/192, pp. 168-171, ISSN: 1310-3946. 